\title{
Role of dinoprostone gel in induction of labour
}

\author{
Meet S. Patel*, Shashwat K. Jani, Babulal S. Patel, Akshay C. Shah
}

Department of Obstetrics and Gynecology, Smt. NHL Municipal Medical College, SVPIMSR, Ahmedabad, Gujarat, India

Received: 29 December 2020

Accepted: 05 February 2021

*Correspondence:

Dr. Meet S. Patel,

E-mail: meetpatel2511@gmail.com

Copyright: (c) the author(s), publisher and licensee Medip Academy. This is an open-access article distributed under the terms of the Creative Commons Attribution Non-Commercial License, which permits unrestricted non-commercial use, distribution, and reproduction in any medium, provided the original work is properly cited.

\section{ABSTRACT}

Background: Labour induction is one of the most common intervention in obstetric practice. A simple application of PGE2 intracervical gel can ripen the cervix effectively and improve Bishop's score there by helping in successful vaginal delivery. Considering its good performance, the dinoprostone slow-release vaginal insert is the first choice for elective induction of labour in postdate pregnancy and in patients with term pregnancy of premature rupture of membranes.

Methods: This was a single year retrospective study conducted in a tertiary care center of western India from May 2019 to May 2020.

Results: In group I women who delivered within 24 hours were included, in group II women who required reinstillation were included. The most common indication for induction in both the groups was past dates (accounting for $36.1 \%$ in group I and $47.3 \%$ in group II). The success rate in group I was $68.1 \%$ while in group II was $36.8 \%$. The rate of cesarean delivery in group I was $25.9 \%$, while in Group II, it was $60.1 \%$. Negligible maternal and neonatal complications were seen in both the groups.

Conclusions: The study showed that intracervical application of prostaglandin E2 is an effective, safe and acceptable method for induction of labor in women with unfavorable cervix and indications for induction. All these effects were achieved without increasing maternal and neonatal morbidity

Keywords: Intracervical prostaglandin E2, Unfavorable cervix, Bishop score, Induction of labour

\section{INTRODUCTION}

Labor is a process through which the fetus moves from the intrauterine to the extrauterine environment. It is a clinical diagnosis defined as the initiation and perpetuation of uterine contractions with the goal of producing progressive cervical effacement and dilatation. Induction of labor is common in obstetric practice. It means deliberate termination of pregnancy beyond 28 weeks by any method which aims at the initiation of labor and vaginal delivery. ${ }^{1-3}$ The goal of modern obstetrics is to improve the safety of the mother and the fetus during the antenatal period as well as parturition. ${ }^{4,5}$ The lowest incidence of perinatal morbidity and mortality occurs around 39-40 weeks of gestation. Therefore, some have advocated induction of uncomplicated singleton gestations once they reach full-term.

\section{METHODS}

This retrospective clinical trial was carried out in the department of obstetrics and gynecology at V. S. General hospital and Sardar Vallabhbhai Patel institute of medical science and research, Ahmedabad from May 2019 to May 2020. The purpose of this study was to evaluate the safety and efficacy of intracervical PGE2 as an inducing agent in women with an unfavorable cervix, at term (Bishop score $\leq 6$ ). This study comprised of 110 women who required labor induction. Inclusion criteria: Singleton pregnancy between 36- 40 weeks live 
intrauterine fetus, cephalic presentation, Bishop score of 1-6, reactive FHR pattern. Exclusion criteria included cephalopelvic disproportion, abnormal fetal heart rate patterns, uterine scar, hypersensitivity to prostaglandins. On admission, a detailed history of the subjects was taken. Complete general and obstetric examination was carried out. Under strict aseptic precautions, the vaginal examination was done. Bishop score was assessed. Once the inclusion criteria were fulfilled, the patient was counseled and written informed consent was obtained. Dinoprostone was instilled intra cervically after ensuring a reactive FHR pattern. Repeat per vaginal examination was done at 6 hours, 12 hours and 24 hours depending upon the improvement in Bishop score. Women were divided into two groups depending on the number of inductions. Necessary blood investigation and ultrasonography of all women were done. Those women who required only single induction and who delivered within 24 hours were categorized as group 1. Women with persistent poor Bishop score $<6$ after 24 hours were re induced and belonged to group 2. Group I had $64.4 \%$ of primi and $35.6 \%$ of multi, while group II had $82.8 \%$ of primi-gravidae and $17.6 \%$ of multi-gravidae which was statistically significant.

The patient monitored carefully and if the patient went in labor which means uterine contractions more than 30 seconds and cervical dilatation more than $3 \mathrm{~cm}$, artificial rupture of membrane was done. If labor did not ensue by 12 hours after second dose of PGE2 gel, then reassessment of Bishop score was done and oxytocin induction started with 2 units Pitocin in $500 \mathrm{ml}$ of $5 \%$ dextrose drip. If labor did not commence within 48 hours patient, patient was taken for caesarean section as a case of failed induction. The statistical analysis was done using Microsoft excel.

\section{RESULTS}

In group I women who delivered within 24 hours (72 cases) were included, in group II: women who required re-instillation (38 cases) were included (Table 2). Group I had $64.4 \%$ of primi and $35.6 \%$ of multi, while group II had $82.8 \%$ of primi-gravidae and $17.6 \%$ of multigravidae which was statistically significant. In group I, $24.7 \%$ and in group II, $31.6 \%$ had various antenatal complications which were comparable. The most common indication for induction in both the groups was past dates (accounting for $36.1 \%$ in group I and $47.3 \%$ in group II). The mean pre-induction Bishop score in group I was 4.03 compared to 2.63 in group II (Table 1 and 3 ).

In group I, 31.9\% had the Bishop score of 4 while in group II, 39.4\% had the Bishop score of 2. Group I, required one induction and delivered within 24 hours. In group II, $76.5 \%$ required two inductions, while 21.5 percent required three inductions, which was statistically significant. In group I, the rate of improvement in Bishop score was satisfactory, i.e., 9.6 at 12 hours and 10.3 at 24 hours. In group II, the mean Bishop score was 5.62 at 12 hours and 7.68 at 24 hours as shown in the Table 4.

Table 1: Pre induction bishop's score.

\begin{tabular}{|lllll|}
$\begin{array}{l}\text { Pre- } \\
\text { induction } \\
\text { Bishop's } \\
\text { score }\end{array}$ & $\begin{array}{l}\text { Group I (within } \\
\text { 24 hours) }\end{array}$ & $\begin{array}{l}\text { Group II (bishop's } \\
\text { score < } \\
\text { hourter } 24\end{array}$ \\
\hline $\mathbf{2}$ & 9 & $\mathbf{\%}$ & No. & \% \\
\hline $\mathbf{3}$ & 15 & 20.8 & 14 & 39.4 \\
\hline $\mathbf{4}$ & 23 & 31.9 & 7 & 18.4 \\
\hline $\mathbf{5}$ & 12 & 16.7 & 2 & 5.2 \\
\hline $\mathbf{6}$ & 13 & 18.1 & & \\
\hline Total & 72 & 100 & 38 & 100 \\
\hline
\end{tabular}

Table 2: Indications for induction.

\begin{tabular}{|lllll|}
\hline $\begin{array}{l}\text { Indication of } \\
\text { induction }\end{array}$ & No. & \% & No. & $\%$ \\
\hline Post-dates & 26 & 36.1 & 18 & 47.3 \\
\hline $\begin{array}{l}\text { Oligohydramnios } \\
\text { (AFI <5) }\end{array}$ & 4 & 5.7 & 2 & 4.3 \\
\hline $\begin{array}{l}\text { Pre-labour } \\
\text { rupture of } \\
\text { membrane }\end{array}$ & 20 & 27.7 & 1 & 2.6 \\
\hline $\begin{array}{l}\text { Gestational } \\
\text { hypertension }\end{array}$ & 7 & 9.7 & 5 & 13.9 \\
\hline $\begin{array}{l}\text { Pre-eclampsia } \\
\text { Low normal } \\
\text { liquor (AFI 5-8) }\end{array}$ & 3 & 4.1 & 3 & 9.2 \\
\hline Other & 7 & 6.9 & 7 & 18.4 \\
\hline Total & 72 & 100 & 38 & 100 \\
\hline
\end{tabular}

Table 3: Number of PGE 2 gel application.

\begin{tabular}{|lllll|}
\hline $\begin{array}{l}\text { Number of } \\
\text { PGE gel } \\
\text { application }\end{array}$ & No. & \% & No. & $\%$ \\
\hline $\mathbf{1}$ & 72 & 100 & - & - \\
\hline $\mathbf{2}$ & - & - & 29 & 76.5 \\
\hline $\mathbf{3}$ & - & - & 8 & 21.5 \\
\hline $\mathbf{4}$ & - & - & 1 & 2 \\
\hline Total & 72 & 100 & 38 & 100 \\
\hline
\end{tabular}

Table 4: Post induction bishop's score.

\begin{tabular}{|llllll|}
$\begin{array}{l}\text { Post } \\
\text { induction }\end{array}$ & Group I & \multicolumn{3}{l}{ Group II } & P \\
\hline $\begin{array}{l}\text { Bishop's } \\
\text { score } \\
\text { (hours) }\end{array}$ & Mean & S.D. & Mean & S.D. & value \\
\hline $\mathbf{6}$ & 7.8 & 2.20 & 4.05 & 1.42 & 0.0001 \\
\hline $\mathbf{1 2}$ & 9.6 & 2.41 & 5.62 & 2.5 & 0.0001 \\
\hline $\mathbf{2 4}$ & 10.3 & 2.16 & 7.68 & 3.4 & 0.0001 \\
\hline
\end{tabular}

The success rate in group I was $68.1 \%$ while in group II was $36.8 \%$. The rate of cesarean delivery in group I was $25.9 \%$, while in group II, it was $60.1 \%$. The mean 
induction delivery interval in group I was 8 hours and in group II, was 37.5 hours (Table 5).

The most common indication for cesarean delivery in' group I was fetal distress while in group II, it was failed induction. Negligible maternal and neonatal complications were seen in both the groups. The mean birth weight in both the groups was comparable (Table 6 and 7).

Table 5: Mode of delivery.

\begin{tabular}{|lllll|}
\hline $\begin{array}{l}\text { Mode of } \\
\text { delivery }\end{array}$ & No. & \% & Noup & \% \\
\hline $\begin{array}{l}\text { Vaginal } \\
\text { delivery }\end{array}$ & 49 & $68.1 \%$ & 14 & 36.8 \\
\hline $\begin{array}{l}\text { Outlet } \\
\text { forceps }\end{array}$ & 2 & 2.6 & 1 & 3.1 \\
\hline $\begin{array}{l}\text { Vacuum } \\
\text { delivery }\end{array}$ & 3 & 3.4 & - & - \\
\hline $\begin{array}{l}\text { Emergency } \\
\text { cesarean }\end{array}$ & 19 & 25.9 & 23 & 60.1 \\
\hline Total & 72 & 100 & 38 & 100 \\
\hline
\end{tabular}

Table 6: Indication of cesarean.

\begin{tabular}{|lll|ll|}
\hline $\begin{array}{l}\text { Indication of } \\
\text { cesarean }\end{array}$ & No. & \% & No. & \% \\
\hline $\begin{array}{l}\text { Secondary arrest } \\
\text { of labour }\end{array}$ & 1 & 5.2 & - & - \\
\hline Borderline pelvis & 1 & 5.2 & 1 & 4.3 \\
\hline Failed induction & - & - & 8 & 32.4 \\
\hline Fetal distress & 8 & 42.5 & 6 & 27.7 \\
\hline $\begin{array}{l}\text { Non progress of } \\
\text { labour }\end{array}$ & 3 & 15.7 & 3 & 14.1 \\
\hline $\begin{array}{l}\text { Oligohydroamnios } \\
\text { Pre-labour }\end{array}$ & 1 & 5.2 & 2 & 8.6 \\
$\begin{array}{l}\text { rupture of } \\
\text { membrane }\end{array}$ & 2 & 10.5 & 1 & 4.3 \\
\hline Thick MSAF & 2 & 10.5 & 2 & 8.6 \\
\hline $\begin{array}{l}\text { Other reason* } \\
\text { Total }\end{array}$ & 1 & 5.2 & - & - \\
\hline *Maternal fatigue & 19 & 100 & 23 & 100 \\
\hline
\end{tabular}

Table 7: Birth weight.

\begin{tabular}{|lllll|}
\hline Birth weight & Group I & \multicolumn{3}{l|}{ Group II } \\
\hline (kg) & No. & \% & No & \% \\
\hline$<\mathbf{2 . 5}$ & 9 & 12.9 & 4 & 9.4 \\
\hline$\geq \mathbf{2 . 5}$ & 63 & 87.1 & 34 & 90.6 \\
\hline Total & 72 & 100 & 38 & 100 \\
\hline Mean & $2.94 \pm 0.43$ & & $2.96 \pm 0.4$ & \\
\hline P value & 0.9541 & & & \\
\hline
\end{tabular}

\section{DISCUSSION}

Labour induction is one of the most common intervention in obstetric practice. A simple application of PGE2 intracervical gel can ripen the cervix effectively and improve Bishop's score there by helping in successful vaginal delivery. However better outcome always depends on awareness of contraindication, proper application and understanding of possible complications and handling then effectively. Preinduction cervical ripening with the dinoprostone slow-release vaginal insert is associated with a high rate of women undergoing vaginal delivery within 24 hours, with a shorter stay. Considering its good performance, the dinoprostone slow-release vaginal insert is the first choice for elective induction of labour in postdate pregnancy. Fetal distress was less common following PGE2 treatment. Epidural analgesia and postpartum hemorrhage were both reduced following PGE2-induced labour. Use of dinoprostone vaginal inserts in patients with term pregnancy of premature rupture of membranes reduced both the latent phase of labour and total delivery time without increasing the rate of caesarean section. An isolated report of three cases of anaphylactoid reaction after intracervical dinoprostone gel was found during a literature search. As a potentially life-threatening condition, every obstetrician should be aware of this rare complication of dinoprostone gel. Our study enrolled 110 women who required labor induction. All patients were induced with cervi prime gel after satisfying the inclusion criteria. The mean age in both the groups was comparable. There were $70(63.6 \%)$ Primi-gravidae and $40(36.4 \%)$ multi-gravidae. The subjects were divided into two groups: group 1-women who delivered within 24 hours and group 2-women who required re instillation. The similar methodology was adapted by Warke et al who divided the subjects into two groups. ${ }^{6}$ Dinoprostone (PGE2) was instilled intracervical in our study. Ekman's group in Malmo, Sweden has demonstrated in a randomized study that patients with a highly unfavorable cervix apparently respond best to intracervical application of the prostaglandin E2 gel. The Ekman's group achieved cervical ripening, induction of labor and delivery with an $8 \%$ cesarean rate. $^{7}$

In our study, the most common indication for induction was past dates (47.3\%). Which is comparable with a study done by Warke et al where the most common indication was past dates $(52 \%){ }^{6}$ The results were compared with the study done by Turner. $^{8}$ The categorization into groups in the present study was based upon the number of inductions. Reinduction was required in $43.2 \%$ of primigravidae and $17.5 \%$ of multigravidae. Before and after induction, the cervical assessment was done using modified Bishop score (Calder) and rate of improvement in scores were observed. ${ }^{9}$ We found that a higher cervical score correlated with shorter labor and few induction failures. The success of induction of labor was found to be directly proportional to the Bishop score at instillation. In a study done by Calder et al, the cervical score had improved from a mean of 2.3 to 6.3 in 6 hours. ${ }^{9}$ The rate of improvement in Bishop score, in this study, was comparable to the results shown by Warke et al. ${ }^{6}$ The first instillation in our study caused an increase in $2-6$ points in Group 1 while in Group 2 the increase was 2 
points after the first instillation. Group 2 had a mean preinduction Bishop score of 2.9, and subsequent inductions resulted in poor improvement in scores (probably this group included more primis and the most common indication was past dates). In our study success of induction refers to achieving vaginal delivery. Failed induction is defined as failure to enter active phase of labor even after three inductions. In this study, $68.1 \%$ had vaginal delivery compared to study done by Warke et al which was $85.5 \% .^{6}$ The rate of failed induction was $32.4 \%$ in group 2. The largest reported study was conducted by Noah et al in 1986 and involved a multicenter trial under a single protocol in 16 centers in Africa where successful induction was achieved in $83 \%$. The induction delivery interval was shortened and fewer cesarean deliveries were performed (16\%). ${ }^{10}$ Similarly, the success of induction in a study done by Calder et al was $61 \%$ and $75 \%$ as per Jackson et al. ${ }^{11}$ The PGE2 gel has shown to shorten the induction delivery interval and thus results in less fetal and maternal morbidity and mortality. The overall mean induction delivery time was 16.43 hours.

Various studies have shown considerable variation as far as induction delivery time is concerned ranging from 9 hours (Noah et al) to 17.9 hours (Thiery et al) 13 to 20.2 hours in a study done by Jackson and 10 hours in a study by Calder et al. ${ }^{10-12}$ The parity of the patients also influenced the duration of labor. In this study, mean induction delivery interval in primi-gravidae was 20.4 hours and in multi-gravidae was 10.6 hours. The success rate in group 1 was $68.1 \%$ and in group 2 was $36.8 \%$. Group 2 had less success rate when compared to group 1 because $82.8 \%$ were primigravidae $47.3 \%$ were induced for postdates Mean pre-induction Bishop score was only 2.9. The overall success rate regarding vaginal delivery was $68.1 \%$ in group 1 and $36.8 \%$ in group 2 in our study. Present data from worldwide prospective investigations strongly suggest that local PGE2 therapy has few maternal side effects and favorable neonatal outcomes. In our study, the side effects were minimal and neonatal outcome was good.

So, we concluded that Dinoprostone gel application is efficient in achieving cervical ripening and successful labour with reduction in latent phase of labour and total delivery time without increasing the rate of caesarean section and obstetric risk. Limitation of this study is that I have studied 110 patients, so I can't implicate result over whole population.

\section{CONCLUSION}

Our study suggests that dinoprostone gel application is efficient in achieving cervical ripening and successful labour in nulliparous as well as multiparous along with reduction in latent phase of labour and total delivery time without increasing the rate of caesarean section and obstetrical risk. Secondary application of PGE2 gel significantly improves the chances of cervical ripening in cases who had unfavorable cervix and so there is an improvement in Bishop's score. There is decrease in total duration of labour and increase in the chances of vaginal deliveries but strict vigilance is required for both maternal and fetal parameters specially in cases of second applications the study showed that intracervical application of prostaglandin E2 is an effective, safe and acceptable method for induction of labor in women with unfavorable cervix and indications for induction. All these effects were achieved without increasing maternal and neonatal morbidity. Hence PGE2 gel can be recommended as a useful and potent method of induction of labor with an unfavorable cervix (Bishop score $\leq 6$ ). Considering the good performance of maternal and neonatal outcome the dinoprostone gel can be used as the first choice for elective induction of labour in term pregnancy.

\section{Funding: No funding sources}

Conflict of interest: None declared

Ethical approval: The study was approved by the Institutional Ethics Committee

\section{REFERENCES}

1. Grant JM. Induction of Labour. In. James DK, Steer PJ, Weiner CP, Gonik B. High Risk Pregnancy: management Options. 1999;2:1079-101.

2. Induction of Labour. Evidence based clinical guideline No.9. 2001.

3. American College of Obstetricians and Gynaecologists. Induction of Labour. Washington DC: ACOG. 1999;10.

4. Cruz AS, Pinto JM, Valerioo. PGE-2 gel for enhancement of priming and induction of labour at term in patients with unfavorable cervix. Europe $\mathbf{J}$ Obstet Gynaeco Reprod Biol. 1985;20:331-6.

5. Noah ML, Decoster JM, Fraser W. Preinduction cervical softening with endocervical PGE2 gel. A multicenter trial. Acta Obstet Gynecol scand. 1987;66:3-7.

6. Warke HS, Saraogi RM, Sanjwalla SM et al. Prostaglandin E2 gel in ripening of cervix in induction of labor. $\mathrm{J}$ postgraduate med.1999;45(4):105-9.

7. Ekman G, Forman A, Marsál K, Ulmsten U. Intravaginal versus intracervical application of prostaglandin E2 in viscous gel for cervical priming and induction of labor at term in patients with an unfavourable cervical state. Am J Obstet GynecoI. 1983;147:657.

8. Turner JE, Burke MS, Poreeco RP, Weiss MA. Prostaglandin E2 in tylose gel for cervical ripening before induction of labour. $\mathrm{J}$ Reprod Med. 1987;32:815-21.

9. Calder AA, Embrey MP. Prostaglandins and the unfavorable cervix. Lancet. 1973;2:1322.

10. Noah ML, Decoster JM, Fraser W. Preinduction cervical softening with endocervical PGE2 gel. A 
multicenter trial. Acta Obstet Gynecol Scand. 1987;66:3-7.

11. Jackson GM, Sharp HT, Varner MW. Cervical ripening before induction of labor: A randomized trial of prostaglandin E2 versus low dose oxytocin. Am J Obstet Gynecol. 1994;171:1092-96.

12. Thiery M, Decoster JM, Parewijck W, Noah ML et al. Endocervical prostaglandin E2 gel for preinduction cervical softening. Clin Obstet Gynecol. 1984;27:42.

Cite this article as: Patel MS, Jani SK, Patel BS, Shah AC. Role of dinoprostone gel in induction of labour. Int J Reprod Contracept Obstet Gynecol 2021;10:1017-21. 